\title{
DATING OF THE WENLOCK CARBONATE SEQUENCES IN ESTONIA AND STRATIGRAPHIC BREAKS
}

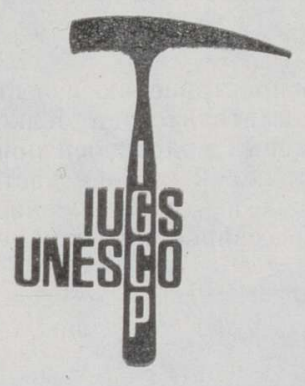

GLOBAL BIOEVENTS

During the Wenlock time progressive shallowing took place in many sedimentary basins (McKerrow, 1979; etc.) including the Baltic basin (Эйнасто, 1986; Bassett et al., 1989; etc.), accompanied by remarkable litho- and biofacies changes. This complicates biostratigraphic correlation as different parts of local geological sections may contain representatives of quite different groups of fossils. The most difficult is the situation in the shallow-water carbonate sequences in the East Baltic where the upper part of the Wenlock and the Wenlock-Lualow transition are dominated by cyclically alternating lagoonal dolostones and sparitic calcarenites (often secondarily dolomitized), containing only sporadically specific, impoverished biota. Therefore, so far exact dating of this part of the sequence in Estonia has been practically impossible. The main aim of the present paper is to shorten the biostratigraphically unidentifiable interval at the Wenlock-Ludlow transition as much as possible and to discuss the stratigraphical completeness of these poorly dated extremely shallowwater sequences.

The preciseness of the dating of the carbonate sections in Estonia depends on their correlation with the continuous graptolitic sequences in the central part of the Baltic syneclise including West Latvia (see Кальо et al., 1984; etc.). Correlation with the Gotland sequence is also of some help as there the Wenlock-Ludlow transition is represented by fossil-rich normal-marine facies (see V. Nestor, 1982).

\section{Main types of sequences}

Three main types of Silurian sequences have been distinguished in the northern East Baltic (Кальо, 1977; etc.): 1. Sequences of predominately carbonate rocks in Central Estonia, and on Hiiumaa and Saaremaa Islands. 2. Transitional carbonate-argillaceous sequences (prevailingly marlstones) in South Estonia and North Latvia (including Sõrve Peninsula of Saaremaa). 3. Sequences of highly argillaceous rocks (mudstones, argillites) with graptolites in West Latvia and West Lithuania.

Different stratigraphic nomenclature has been used for these types of sequences (Fig. 1).

\footnotetext{
* Eesti TA Geoloogia Instituut (Institute of Geology, Estonian Academy of Sciences), Estonia pst. 7, 200105 Tallinn, Estonia.
} 


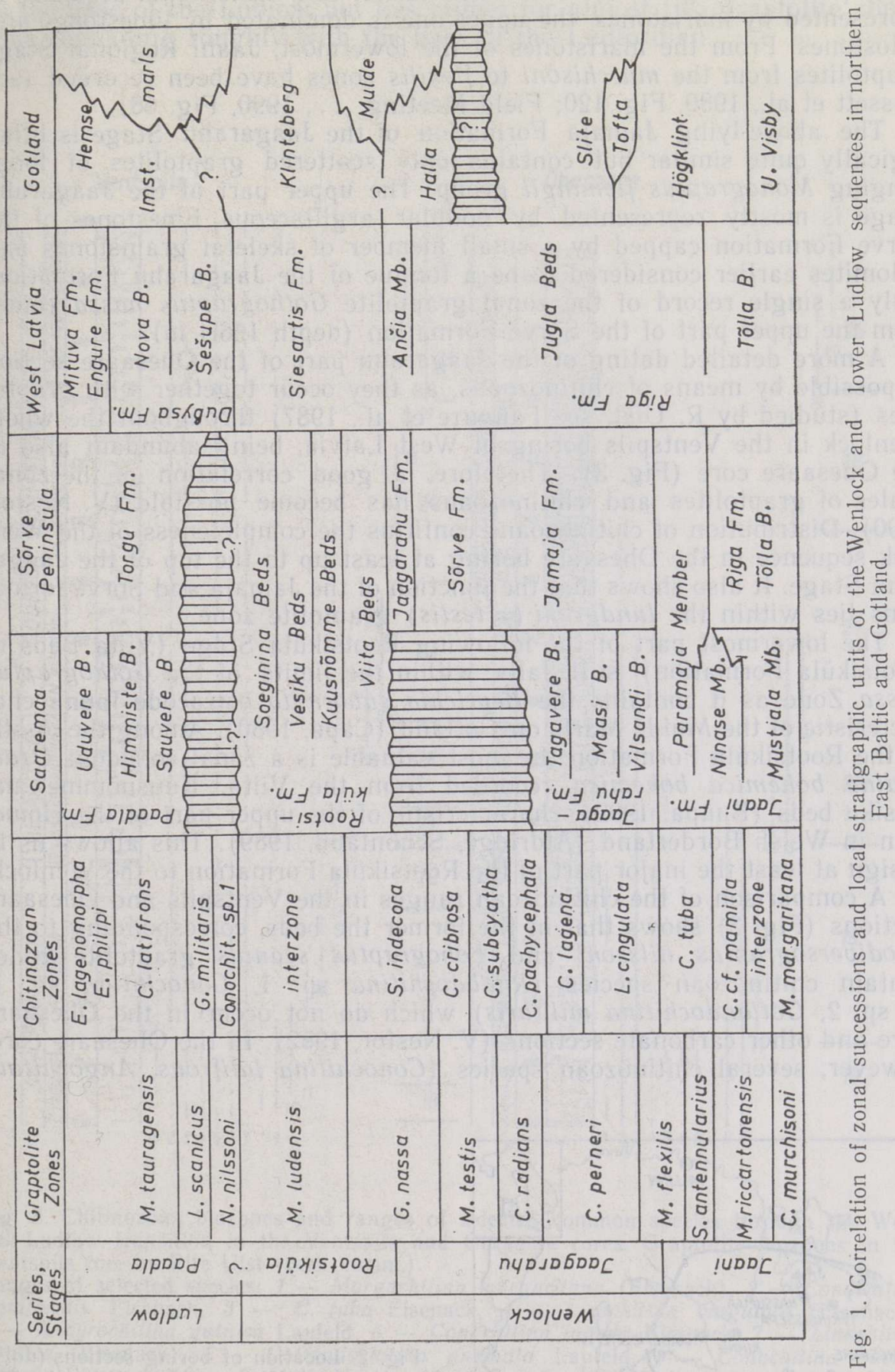


By the correlation of carbonate sequences of Estonia with the graptolite succession, the Ohesaare core from the Sõrve Peninsula of Saaremaa holds a key position (Figs. 2, 3). The lower half of this transitional sequence is represented by marlstones, the upper one is dominated by limestones and dolostones. From the marlstones of the lowermost, Jaani Regional Stage graptolites from the murchisoni to flexilis zones have been recorded (see Bassett et al., 1989, Fig. 120; Field Meeting ..., 1990, Fig. 58).

The above-lying Jamaja Formation of the Jaagarahu Stage is lithologically quite similar but contains only scattered graptolites of longranging Monograptus flemingii group. The upper part of the Jaagarahu Stage is mostly represented by nodular argillaceous limestones of the Sõrve Formation capped by a small member of skeletal grainstones and dolomites earlier considered to be a tongue of the Jaagarahu Formation. Only a single record of the zonal graptolite Gothograptus nassa comes from the upper part of the Sorve Formation (depth $166.4 \mathrm{~m}$ ).

A more detailed dating of the Jaagarahu part of the Ohesaare section is possible by means of chitinozoans, as they occur together with grapto: lites (studied by R. Ulst, see Гайлите et al., 1987) throughout the whole Wenlock in the Ventspils boring of West Latvia, being abundant also in the Ohesaare core (Fig. 3). Therefore, a good correlation of the zonal scales of graptolites and chitinozoans has become possible (V. Nestor, 1990). Distribution of chitinozoans confirms the completeness of the Wenlock sequence in the Ohesaare boring at least up to the top of the Jaagarahu Stage. It also shows that the junction of the Jamaja and Sõrve formations lies within the lundgreni ( $\approx$ testis) graptolite zone.

The lowermost part of the following Rootsiküla Stage (Viita Beds of Rootsiküla Formation) still falls within the limits of the Gothograptus nassa Zone as it contains the Beyrichia subornata ostracode fauna characteristic of the Mulde Marls on Gotland (Сарв, 1980). Among the fossils of the Rootsiküla Formation the most valuable is a zonal conodont Ozarkodina bohemica bohemica recorded from the Viita, Kuusnomme and Vesiku beds (Вийра, 1982), characteristic of the upper part of the Homerian in Welsh Borderland (Aldridge, Schönlaub, 1989). This allows us to assign at least the major part of the Rootsiküla Formation to the Wenlock.

A comparison of the chitinozoan ranges in the Ventspils and Ohesaare sections (Fig. 3) shows that in the former the beds, corresponding to the Neodiversograptus nilssoni and Lobograptus scanius graptolite zones contain chitinozoan species (Rhabdochitina sp. 1, Conochitina sp. 1, C. sp. 2, Gotlandochitina militaris) which do not occur in the Ohesaare core and other carbonate sections (V. Nestor, 1982). In the Ohesaare core, however, several chitinozoan species (Conochitina latifrons, Angochitina

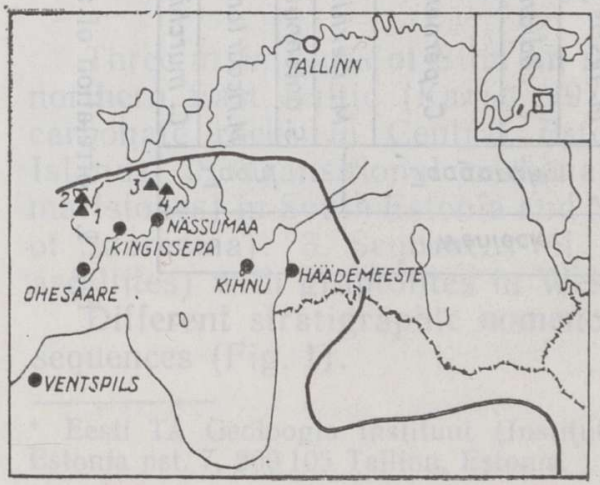

Fig. 2. Location of boring sections (dots) and outcrops (triangles), and the distribution of the Wenlock rocks (thick contour line). Outcrops of the Jaagarahu Stage: 1 - Jaagarahu, 2 - Sepise, 3 - Tôre, 4 - Tagavere, 
elongata, etc.) appear successively in the Torgu Formation of the Paadla Stage; these species appear exactly in the same order in the Ventspils section starting from the top of the scanicus Zone. Consequently, the base of the Paadla Stage in the Estonian carbonate sections does not correspond to the base of the Ludlow but lies higher for almost two graptolite zones, thus coinciding roughly with the base of the Ludfordian.

Ventspils

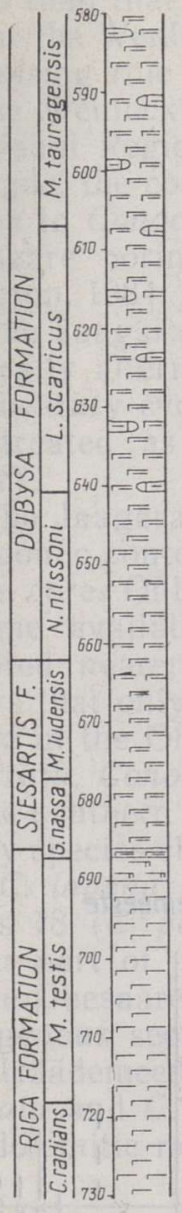

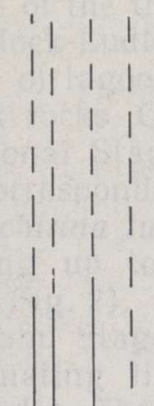

25

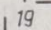

18

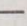

के

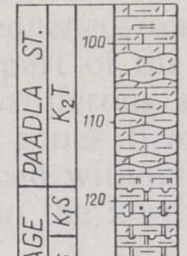

1

11

125

20

19

22

21

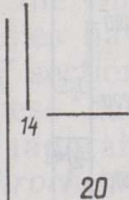

19

18

Fig. 3. Chitinozoan biozones and ranges of selected common species through the Wenlock-Ludlow transition in the Ventspils and Ohesaare cores. Graptolite biozones in the Ventspils core by Rita Ulst (pers. comm.).

Ranges of selected species: 1 - Margachitina margaritana (Eisenack), 2 - Conochitina claviformis Eisenack, 3- C. tuba Eisenack, 4-Linochitina cingulata (Eisenack), 5 - Ancyrochitina gutnica Laufeld, 6 - Conochitina lagena Eisenack, 7 - Linochitina erratica (Eisenack), 8 - Gotlandochitina uncinata Laufeld, 9 - Conochitina pachycephala Eisenack, $10-C$. fortis Nestor, 11 - C. subcyatha Nestor, 12 - Ancyrochitina cf. sp. b, 13 - Conochitina cribrosa Nestor, $14-C$. cf. argillophila Laufeld, $15-$ Rhabdochitina sp. 1, 16-Conochitina sp. 1,17-C. sp. 2,18-Gotlandochitina militaris Laufeld, 19 - Conochitina latifrons Eisenack, 20 - Angochitina elongata Eisenack. Chitinozoan biozones: $18-C$. pachycephala Zone, $19-C$. subcyatha Zone, $20-$ C. cribrosa Zone, 21 - S. indecora Zone, 22 - interzone, 23 - C. sp. 1 Zone, 24 C. sp. $2-G$. militaris Zone, $25-C$. latifrons Zone. Lithological legend see Fig. 5. 
This is also proved by the distribution of ostracodes. The Estonian carbonate sequences do not contain ostracodes of the Amphitoxotis curvata and Craspedobolbina robusta fauna characteristic of the lower part of the Hemse Marls, containing graptolites of nilssoni and scanicus zones. The Paadla Stage contains Neobeyrichia nutans fauna characteristic of the middle part of the Hemse Beds on Gotland (Sarv, 1982).

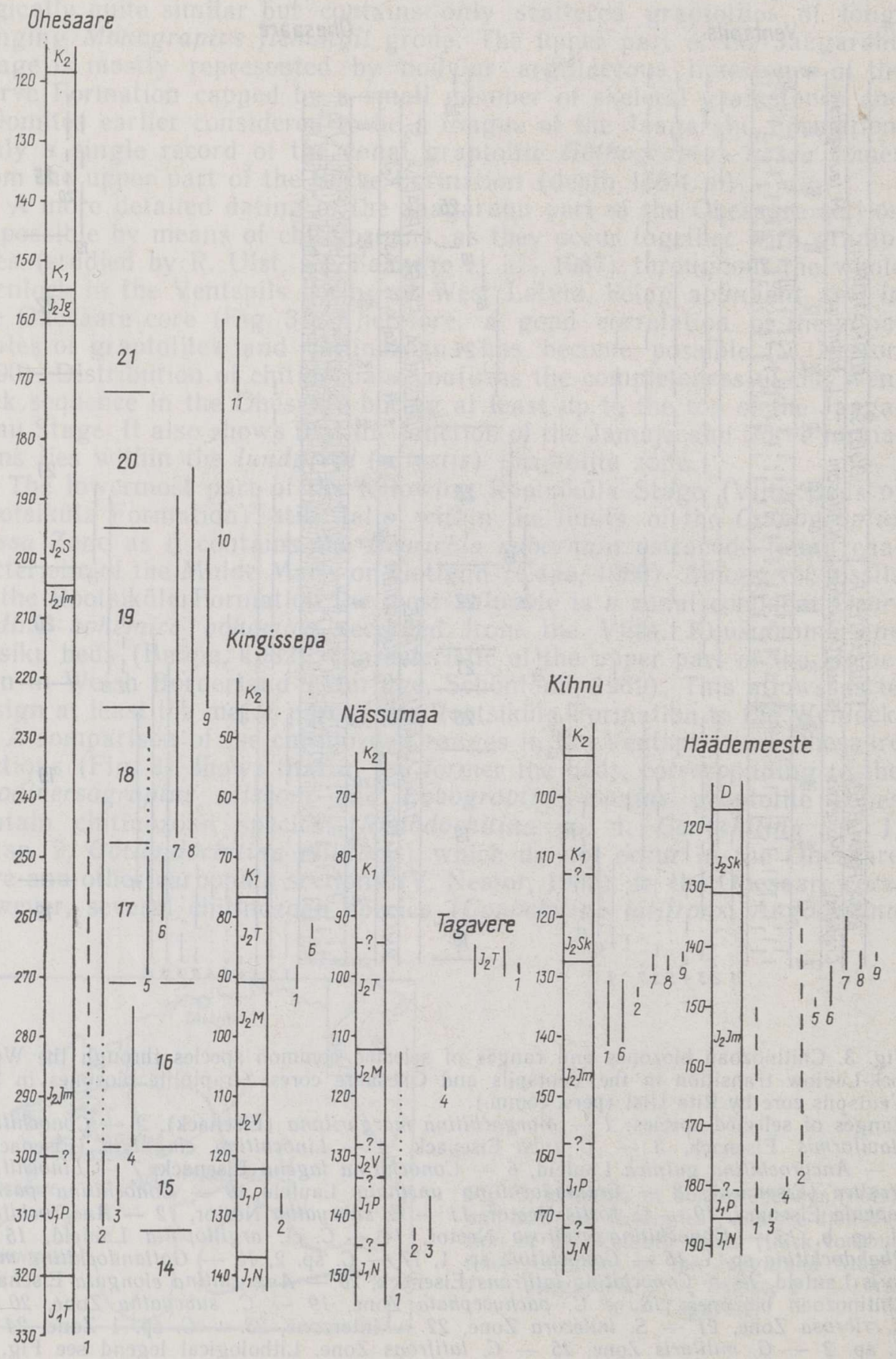


Considering these data in the recent correlation charts (Решения..., 1987) a hiatus has been shown in the lower part of the Ludlow in Estonian sequences. Still, a certain part of the Rootsiküla Stage may correspond to the lower Ludlow zones. Particularly it concerns the topmost part the Soeginina Beds where no guide fossils have been found up to now.

\section{Carbonate sequences}

Because of the lack of graptolite records exact dating of the classical carbonate sequences in the outcrop area of Estonia is much more complicated than that of the transitional sequences, and the unidentifiable interval at the Wenlock-Ludlow transition increases. This is connected with the increasing role of lagoonal facies in sequences and strong dolomitization of the Wenlock rocks. Only the lower part of the Wenlock sequence, i. e. the Jaani Regional Stage is highly fossiliferous and well correlated. For example, the corresponding chitinozoan zones (from Margachitina margaritana to Conochitina tuba) can be traced without any difficulty from the Ohesaare boring up to the outcrops on the northern coast of Saaremaa (Нестор, 1984, Fig. 2).

The Jaagarahu Stage is represented in its stratotype area by various cyclically alternating limestones and dolostones, forming shallowing-up sedimentary cycles. Three mesocycles, terminating in lagoonal dolomites, are treated as the Vilsandi, Maasi and Tagavere beds (in ascending order).

The Jaagarahu Formation contains fossils only sporadically and their taxonomic content is quite different from that of the fossils from the Ohesaare core. Only recently scattered records of chitinozoan species have become available from some outcrops (Tagavere) and boring sections situated nearer to the outcrop area (Fig. 4). Comparison of these data shows that only the species, diagnostic of the lower half of the Jaagarahu Stage in the Ohesaare section (Ancyrochitina pachyderma, Clathrochitina clathrata, Conochitina argillophila, etc.) have been found in the sections of the southern coast of Saaremaa (Kingissepa, Nässumaa). They contain solely species characteristic of the chitinozoan zones 16 ( L. cingulata) and 17 (C. lagena), while there is no information about the presence of the zones 18 (C. pachycephala) to 21 ( $S$. indecora) corresponding to the upper part of the Jamaja Formation and to the whole Sorve Formation in the Ohesaare core (see V. Nestor, 1990). In the transitional, carbonateterrigenous sections, situated eastwards from the Ohesaare core (Kihnu and Häädemeeste, Fig. 4) the index species of zones 18 and 19 (C. pachycephala and $C$. subcyatha) have been established from the upper part of the dolomitic marlstones attributed to the Jamaja Formation, followed by

Fig. 4. Ranges of selected chitinozoan species in some middle and upper Wenlock sections of West Estonia.

Indices of stratigraphic units: $J_{1}$ - Jaani Regional Stage; $J_{1} T-$ Tõlla Formation; $J_{1} N-$ Ninase Formation; $J_{1} P-$ Paramaja Formation; $J_{2}-$ Jaagarahu Regional Stage; $J_{2} J m$ - Jamaja Formation, $J_{2} \mathrm{~S}$ - Sõrve Formation; $J_{2} J g$ - Jaagarahu Formation, $J_{2} V-$ Vilsandi Beds, $J_{2} M-$ Maasi Beds, $J_{2} T$ - Tagavere Beds, $J_{2} S k-$ Sakla Beds: $K_{1}$ - Rootsiküla Regional Stage; $K_{2}$ - Paadla Regional Stage; $D$ - Devonian.

Ranges of selected species: 1 - Ancyrochitina pachyderma Laufeld, 2 - A. sp. b, 3 - Desmochitina acollaris Eisenack, 4 - Clathrochitina clathrata Eisenack, 5 - Conochitina lagena Eisenack, $6-C$. argillophila Laufeld, $7-C$. pachycephala Eisenack, 8 - C. fortis Nestor, $9-$ C. subcyatha Nestor, $10-$ C. cribrosa Nestor, $11-$ Sphaerochitina indecora Nestor.

Chitinozoan biozones: 14 - Conochitina cf. mamilla Zone, 15 - C. tuba Zone, 16 Linochitina cingulata Zone, 17 - Conochitina lagena Zone, 18 - C. pachycephala Zone, 19 - C. subcyatha Zone, 20 - C. cribrosa Zone, 21 - Sphaerochitina indecora Zone, 22 - interzone. 
almost barren dolostones of the Sakla Formation. This indicates rapid increase in the stratigraphic extension of the Jaagarahu Stage to the south.

On the basis of the identical cyclic structure of the sections and the presence of several common fossils (Ctenognathodus murchisoni, Ozarkodina bohemica bohemica, Logania martinssoni, Howellella cuneata, Parastriatopora commutabilis, etc.), the boundaries of the above-lying Rootsiküla Stage are considered more or less synchronous in the whole northern East Baltic from the outcrop area to the Ohesaare section.

\section{Correlations by corals and stromatoporoids}

As in the Wenlock and Ludlow outcrops of Estonia tabulate corals and stromatoporoids are among the most common fossils, it is reasonable to examine how they support or contradict the chitinozoan correlation. Most of the stromatoporoid and tabulate finds from the outcrops come from the Mustjala Member of the Jaani Formation and from the Vilsandi and Maasi beds of the Jaagarahu Formation, which in Gotland sequence are well correlated with the Upper Visby, upper Högklint and Slite Beds, respectively (see H. Nestor, 1982, 1990; Клааманн, 1982, 1983, 1986).

Kingissepa boring section offers some additional information to the data from outcrops (Fig. 5). It shows the same species which have been established from the Tõre outcrop and which belong to the Halysites junior-Palaeofavosites tersus Community of tabulates (Клааманн, 1986) or Ecclimadictyon astrolaxum Community of stromatoporoids (H. Nestor, $1982,1990)$ to be the most common ones in the upper part of the Maasi Beds. In the Tagavere Beds of the Kingissepa core the frequency and diversity of tabulates and stromatoporoids decrease abruptly. Only a few species (Palaeofavosites asper, Pf. pauculus, Barrandeolites lichenarioides) common with the Maasi Beds, have been found in this part of the section. In the upper part of the Tagavere Beds a specific Riphaeolites lamelliformis tabulate community has been established (Клааманн, 1983, 1986). Among stromatoporoids only unidentifiable specimens of Ecclimadictyon have been recorded in the uppermost Tagavere Beds. These data are too scanty for a definite correlation of the Tagavere Beds with the Gotland sequence.

The Halla Beds on Gotland contain some stromatoporoid and tabulate species which occur also in the Wenlock Limestone in England (Wenlock Edge and Dudley area): Labechia conferta, Clathrodictyon striatellum, Thecia expetiata (H. Nestor, 1982; Қлааманн, 1982). The first two species occur also in the Muksha Beds of Podolia, therefore the absence of these wide-spread species in the Estonian sequence (especially of a very prominent stromatoporoid - Labechia conferta) may serve as an argument for the absence of analogues of the Halla Beds in the outcrop area of Estonia.

In the cyclically alternating lagoonal dolomites and different calcarenitic rocks of the nominal formation of the Rootsiküla Stage only impoverished specific communities of Parastriatopora commutabilis (tabulates) and Araneosustroma stelliparratum (stromatoporoids), the most typically developed in the Kuusnommme Beds, have been established. In the Gotland sequence species of these communities are unknown, but the Parallelostroma tenellum Community in the Klinteberg Beds is supposed to be a lateral equivalent of the Araneosustroma stelliparratum Community because in the Khatanzei section of Novaya Zemlya Island index species of these two communities have been found together in the upper part of the Klenova Formation (H. Nestor, 1982; Hестор, 1981). At least a partial correlation of the Rootsiküla Stage with the Klinteberg Beds is also proved by a 
record of the brachiopod Conchidium biloculare in the Vesiku Beds (Luha, 1930; Рубель et al., 1984). This species is rather common in the lower part of the Klinteberg Beds (Bassett, Cocks, 1974).

The number of the common species of corals and stromatoporoids increases again rapidly in the carbonate sequences of the Paadla Stage and the Hemse Group of the Ludlow age. The most similar are the assemblages in the coral-stromatoporoid build-ups of the Uduvere Beds of Saaremaa and of the Hemse reefs on the Ostergarn Peninsula, Gotland, containing the Laceripora cribrosa - Parastriatopora coreaniformis Community of tabulates, and the Simplexodictyon podolicum Community of stromatoporoids (Клааманн, 1986; H. Nestor, 1990).

Kingissepa (Kuressaare) boring

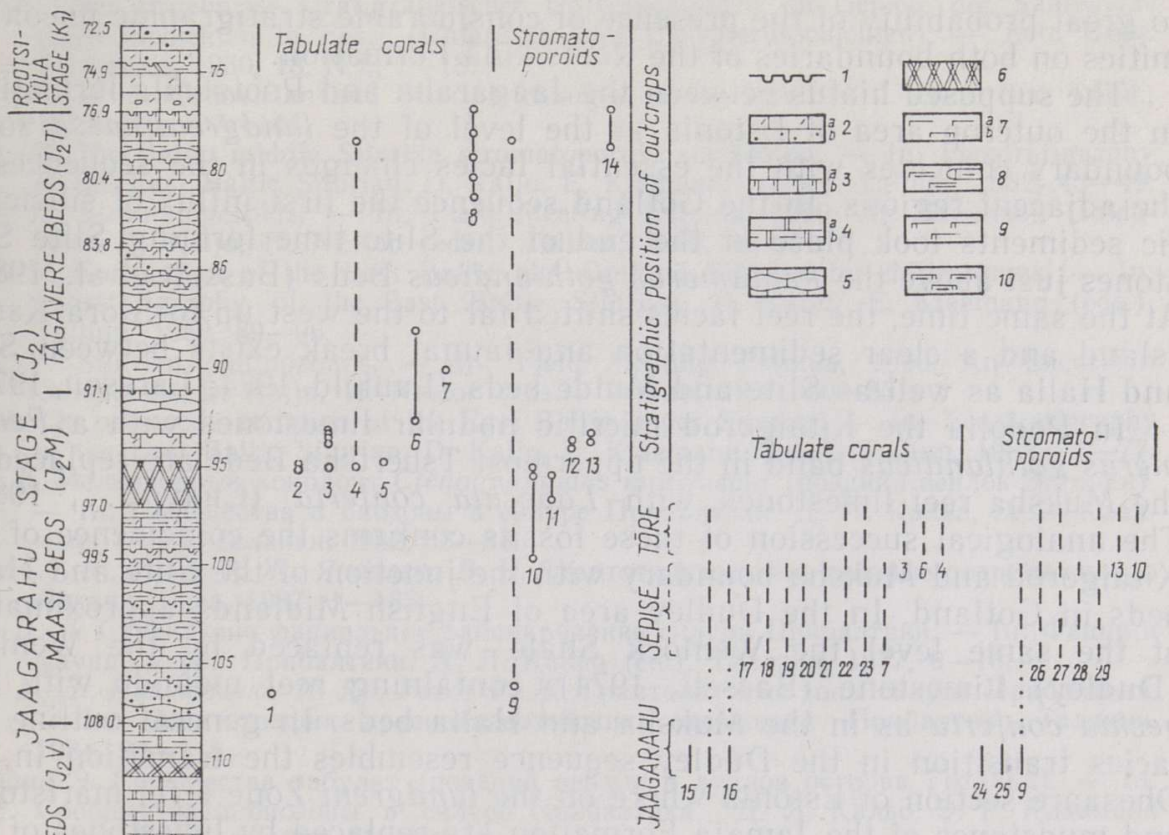

Fig. 5. Stratigraphic distribution of tabulates and stromatoporoids in the Kingissepa core section and in some outcrops of the Jaagarahu Formation.

Lithological legend: 1 - hardground, 2 - skeletal $(a)$ and pelletal (b) limestone, 3 - micritic $(a)$ and dolomitic $(b)$ lmst., 4 - pure $(a)$ and argillaceous $(b)$ dolomite, 5 - nodular lmst., 6 - dolomitized reef lmst., 7 - calcareous $(a)$ and dolomitic (b) marlstone, 8-argillaceous marlstone with lmst. nodules, 9 - calcareous domerite, 10 - dolomitic argillaceous marlstone.

Ranges of species: 1 - Thecia confluens, 2 - Striatopora coenitoides, 3 - Palaeofavosites tersus, 4 - Pf. asper, 5-Parastriatopora priva, 6 - Palaeofavosites pauculus, 7 - Barrandeolites lichenarioides, 8 - Riphaeolites lamelliformis, 9 - Ecclimadictyon macrotuberculatum, 10 - Actinodictyon aff. crispatum, 11 - Ecclimadictyon cf. astrolaxum, 12 - Araneosustroma sp. n., 13 - Ecclimadictyon robustum, $14-$ E. sp. (ex gr. fastigiatum), 15 - Favosites mirandus, 16 - Coenites juniperinus, 17 - Palaeofavosites collatatus, 18 - Pf. parilis, $19-$ Multisolenia excelsa, 20-Aulopora enodis, $21-$ Mastopora foederata, 22 - Halysites junior, 23 - Tuvaelites callosus, 24 - Clathrodictyon kudriavzevi, 25 - Vikingia tenuis, 26 - Simplexodictyon simplex, 27 - Densastroma pexisum, 28 - Simplexodictyon validum, 29 - Ecclimadictyon astrolaxum. 
The above-said proves that there exists quite a good correlation between the lower Wenlock and lower Ludlow stratigraphical units of Gotland and Estonia, whereas it is almost impossible to directly correlate the upper Wenlock and lowermost Ludlow units, particularly the Tagavere + Rootsiküla beds of Estonia and the Halla + Klinteberg beds of Gotland sequences. Indirect data by corals and stromatoporoids support rather than contradict chitinozoan correlations.

\section{Concluding remarks}

Correlation of the upper Wenlock carbonate sequences of Estonia with the more or less continuous sequences in West Latvia and Gotland refer to great probability of the presence of considerable stratigraphic unconformities on both boundaries of the Rootsiküla Formation.

The supposed hiatus between the Jaagarahu and Rootsiküla formations in the outcrop area of Estonia at the level of the lundgreni/nassa zones boundary coincides with the essential facies changes in the sequences of the adjacent regions. In the Gotland sequence the first influx of siliciclastic sediments took place at the end of the Slite time forming Slite Siltstones just above the Pentamerus gothlandicus Beds (Bassett et al., 1989). At the same time, the reef facies shifted far to the west up to Stora Karlsö Island and a clear sedimentation and faunal break exists between Slite and Halla as well as Slite and Mulde beds (Laufeld, 1974; Larsson, 1979).

In Podolia the Kitaigorod micritic nodular limestones with a Pentamerus gothlandicus band in the uppermost Tshertsha Beds are replaced by the Muksha reef limestones with Labechia conferta (Силур...., 1983). The analogical succession of these fossils confirms the coincidence of the Kitaigorod and Muksha boundary with the junction of the Slite and Halla beds in Gotland. In the Dudley area of English Midlands approximately at the same level the Wenlock Shale was replaced by the Wenlock (Dudley) Limestone (Bassett, 1974), containing reef mounds with Labechia conferta as in the Muksha and Halla beds. In general outline the facies transition in the Dudley sequence resembles the transition in the Ohesaare section of Estonia where on the lundgreni Zone level marlstones and mudstones of the Jamaja Formation are replaced by limestones of the Sõrve Formation.

All the above-said shows that on the background of a general regressive development of the Baltic and the adjacent platform margin seas in the Wenlock more abrupt shallowing took place at the time of the lundgreni to nassa graptolite zones, which lead to a break in sedimentation in most onshore carbonate sequences of the East Baltic area. In the whole Baltic region the lundgreni/nassa shallowing event obviously culminated in the early nassa time when in the Baltic syneclise a band of microlaminated marlstones (Ančia Member of the Riga Formation) was formed in the sequence of monotonous graptolitic mudstones. A short transgression impulse followed in the second half of the nassa time coinciding with the basal part of the Rootsiküla Formation in the East Baltic and the Mulde Beds on Gotland. After that, pulsatory shallowing (sea level drop) continued, leading probably to another break in sedimentation between the Rootsiküla and Paadla stages at the beginning of Ludlow, which lasted in the East Baltic carbonate sequences until the late Gorstian. 
Aldridge, R. J., Schönlaub, H. P. Conodonts, - In: A Global Standard for the Silurian Ser., 1989, N 9, 274-279.

Bassett, M. Review of the stratigraphy of the Wenlock series in the Welsh borderland and South Wales. - Palaeontology, 1974, 17, N 4, 745-777.

Bassett, M. G., Cocks, L. R. M. A review of Silurian brachiopods from Gotland. - Fossils and Strata, $1974,3,1-56$.

Bassett, M. G., Kaljo, D., Teller, L. The Baltic region. - In: A Global Standard for the Silurian System. C. H. Holland, M. G. Bassett (eds.). National Museum of Wales, Geol. Ser., 1989, N 9, 158-170.

Field Meeting Estonia, 1990. An Excursion Guidebook. D. Kaljo, H. Nestor (eds.). Tallinn, 1990, 1-209.

Larsson, K. Silurian tentaculitids from Gotland and Scania. - Fossils and Strata, 1979 $11,1-180$.

Laufeld, S. Silurian Chitinozoa from Gotland - Fossils and Strata, 1974, 5, 1-130.

Luha, A. Uber Ergebnisse stratigraphischer Untersuchungen im Gebiete der Saaremaa(Ösel-) Schichten in Eesti (Unterösel- und Eurypterusschichten). - Acta Univ. Tartuensis, 1930, 18, N 6, 1-18.

McKerrow, W. S. Ordovician and Silurian changes in sea level. - J. Geol. Soc. Lond. $1979,136,137-145$.

Nestor, H. The Baltic middle Silurian stromatoporoid succession. - In: Ecostratigraphy of the East Baltic Silurian. D. Kaljo, E. Klaamann (eds.). Tallinn, 1982, 43-49.

Nestor, H. Stromatoporoids. - In: Field Meeting Estonia, 1990. An Excursion Guidebook. D. Kaljo, H. Nestor (eds.). Tallinn, 1990, 46-51.

Nestor, $V$. Correlation of the East Baltic and Gotland Silurian by chitinozoans. - In Ecostratigraphy of the East Baltic Silurian. D. Kaljo, E. Klaamann (eds.) Tallinn, 1982, 89-96.

Nestor, V. Silurian chitinozoans. - In: Field Meeting Estonia, 1990. An Excursion Guidebook. D. Kaljo, H. Nestor (eds.). Tallinn, 1990, 80-83.

Sarv, L. On ostracode zonation of the East Baltic upper Silurian. - In: Ecostratigraphy of the East Baltic Silurian. D. Kaljo, E. Klaamann (eds.). Tallinn, 1982, 71-77.

Buйра B. Мелководный конодонт Ctenognathodus murchisoni (поздний венлок Эстонии). - In: Сообщества и биозоны в силуре Прибалтики. Д. Л. Кальо, Э. Р. Клааманн (eds.). Таллинн, 1982, 63-83.

Гайлите Л. К., Ульст Р. Ж., Яковлева В. И. Стратотипические и типовые разрезы силура Латвии. Рига, 1987, 1-183.

Кальо Д. Л. Структурно-фациальное районирование силура Прибалтики. - Iп: Фации и фауна силура Прибалтики. Д. Л. Кальо (ed.). Таллинн, 1977, 6-13.

Кальо Д. Л.. Пашкевичюс Н. Ю., Ульст Р. Ж. Граптолитовые зоны силура Прибалтики. - In: Стратиграфия древнепалеозойских отложений Прибалтики. Таллинн, $1984,94-118$.

Клааманн Э. Сообщества табулят (поздний венлок и лудлов острова Готланд). - In: Сообщества и биозоны в силуре Прибалтики. Д. Л. Кальо, Э. Р. Клааманн (eds.). Таллинн, 1982, 35-52.

Клааманн Э. Табуляты яаниского и яагарахуского горизонтов (венлок Эстонии) и их биозоны. - In: Палеонтология древнего палеозоя Прибалтики и Подолии. Таллинн, $1983,3-38$.

Клааманн Э. Сообщества и биозональность табулятоморфных кораллов силура Прибалтики. - In: Теория и опыт экостратиграфии. Д. Л. Кальо, Э. Р. Клааманн (eds.). Таллинн, 1986, 80-98.

Нестор В. Зональное распределение хитинозой в яаниском горизонте (венлок Эстонии) и проблема его границ. - In: Стратиграфия древнепалеозойских отложений Прибалтики. Таллинн, 1984, 119-127.

Нестор X. Э. Строматопораты. - In: Объяснительная записка к схеме стратиграфии верхнесилурийских отложений Вайгачско-Южноновоземельского региона. Ленинград, $1981,97-107$.

Решения Межведомственного стратиграфического совещания по ордовику и силуру Восточно-Европейской платформы 1984 г. с региональными стратиграфическими схемами. Ленинград, $1987,1-114$.

Рубель М., Мустейкис П., Попов Л. Е. Систематический список брахиопод силура Прибалтики. Таллинн, $1984,1-36$.

Сарв Л. К составу и распространению поздневенлокской ассоциации остракод в Эстонии. - Изв. АН ЭССР. Геол., 1980, 29, № 3, 89-97.

Силур Подолии. Путеводитель экскурсин. Киев, 1983, 1-224.

Эйнасто $P$. Основные стадии развития и фациальные модели силурийского краевого бассейна Балтики. - In: Теория и опыт экостратиграфии. Д. Л. Кальо, Э. Р. Қлааманн (eds.). Таллинн, 1986, 37-54 


\section{WENLOCKI LADEJARGU KARBONAATLÄBILÖIGETE DATEERIMINE EESTIS JA STRATIGRAAFILISED LUNGAD}

Eesti siluri avamusalal on Wenlocki ladejärgu ülemise osa moodustavad Jaagarahu ja Rootsiküla kihistud esindatud valdavalt kivistisvaeste dolomiitidega, mille täpsem korreleerimine graptoliitide tsonaalse skaalaga on olnud raskendatud. Linochitina cingulata ja Conochitina lagena tsooni kitinozoade leidude pōhjal mõnedest Saaremaa puursüdamikest võib stratotüüpse Jaagarahu kihistu läbilõiget korreleerida Jamaja kihistuga Sõrve poolsaare läbilõigetes (Ohesaare). Sõrve kihistule vastav osa avamusala läbilõigetes arvatavasti puudub. See Jaagarahu ja Rootsiküla kihistute vaheline stratigraafiline lünk vastab graptoliidiskaalas Cyrtograptus lundgreni tsooni ülemisele ja Gothograptus nassa tsooni alumisele osale ning langeb ajaliselt kokku järskude fatsiaalsete muutustega naaberregioonides, olles ilmselt seotud meretaseme ákilise eustaatilise langusega. Teine stratigraafiline lünk Eesti läbilöigetes on oletatavasti Rootsiküla ja Paadla lademe vahel, vastates ligikaudselt Ludlow' ladejärgu alumistele - Neodiversograptus nilssoni ja Lobograptus scanicus'e graptoliiditsoonidele, kuigi pole välistatud, et ka Rootsiküla kihistu võib mõningal määral ulatuda Ludlow' alumiste tsoonide tasemele.

\section{Buйу HECTOP, Хелдур НЕСТОР}

\section{ДАТИРОВАНИЕ ВЕНЛОКСКИХ КАРБОНАТНЫХ РАЗРЕЗОВ В ЭСТОНИИ И СТРАТИГРАФИЧЕСКИЕ ПЕРЕРЫВЫ}

Корреляция яагарахуской и роотсикюлаской свит, образующих верхнюю часть венлокского разреза в полосе силурийских выходов Эстонии, сильно затруднена из-за слабой палеонтологической характеристики этих преимущественно доломитовых толщ. По находкам характерных представителей хитинозоевых зон Linochitina cingulata и Conochitina lagena в некоторых буровых разрезах о-ва Сааремаа удалось сопоставить стратотипическую яағарахускую свиту с ямаяской свитой в разрезах п-ова Сырве (скв. Oхесааре), в то время как возрастные аналоги вышележащей, сырвеской свиты в разрезах полосы выходов, по всей вероятности, отсутствуют. Отмеченный стратиграфический перерыв между яагарахуской и роотсикюлаской свитами соответствует верхней части зоны Cyrtograptus lundgreni и нижней части зоны Gothograptus nassa в граптолитовой последовательности и совнадает по времени с резкими фациальными изменениями в соседних регионах, что явно связано с быстрым эвстатическим понижением уровня моря.

Второй стратиграфический перерыв в эстонских разрезах расположен, вероятно, между роотсикюласким и паадласким горизонтами, приблизительно соответствуя зонам Neodiversograptus nilssoni и Lobograptus scanicus, хотя не исключено, что роотсикюлаская свита может в известной мере охватывать и низы лудлова. 